\title{
Climate change, climate variability, and the future
}

\author{
D. S. WRATT \\ NIWA, Wellington \\ d.wratt@niwa.co.nz
}

New Zealand's farmers have always had to cope with a varying climate - warmer, cooler, wetter and drier than normal seasons are a fact of life. These changes place more demands on farm management in some parts of the country than in others. This paper first discusses some of the variations in climate to date, examines the question of whether they include some long-term trends, and considers likely causes. The paper then examines what is expected in the future, due to both natural factors and to projected changes of greenhouse gas concentration in the atmosphere. The paper concludes with a brief discussion of potential impacts on the pastoral sector, and of adaptation options.

\section{Observed changes and their causes}

Within a given decade, annual temperatures averaged across the whole country can vary between different years by a degree or more. Year-to-year variations in temperature at a given place can be even larger. Rainfall also varies widely from year to year. As an example, annual rainfall at Appleby near Nelson has been as low as $600 \mathrm{~mm}$ and as high as $1200 \mathrm{~mm}$ in the years since 1930. However, superimposed on the year-to-year variation in temperature there has been an overall upward trend of about $0.9^{\circ} \mathrm{C}$ over the last 100 years (Mullan et al. 2008). The rainfall picture is more complex, but the overall picture from analysing data since 1930 has been of an increase in mean and extreme rainfall in the west, with some decreases in mean and extreme rainfall (plus increasing dry spell duration) generally seen in the north and east of both Islands (Griffiths 2007). A detailed analysis of frost occurrences since 1970 (A. Clark pers. comm.) has shown that overall frosts have been decreasing across the country, with about 70 per cent of the 112 individual climate stations analysed exhibiting fewer frost days. However, in some regions the frequency of frosts has increased over this period.

New Zealand temperatures and spatial patterns of rainfall are both sensitive to the direction of air flow over the country. For example, in seasons or years with more southwesterly flow than usual it tends to be cooler. This is typically the case for El Niño conditions, when the more predominant southwesterly flow often also produces wetter conditions in the south and west of the South Island, and drier conditions in the east and north of the country (Mullan 1995; Salinger et al. 2004). The overall picture for La Niña conditions is the opposite. Much of the year-to-year variation in temperature and rainfall is due to natural causes such as the El Niño - La Niña cycle, and to what is sometimes called "climate noise" (random fluctuations in the number and intensity of storms crossing the country). Pastoral farmers have gained experience in how to farm for these conditions, including coping with droughts (although these can still cause major difficulties). There are also multidecadal changes associated with a feature called the Inter-decadal Pacific Oscillation (Salinger et al. 2004). Changes in dominant flow patterns can lead to changes in cloudiness as well as temperature - both of which can affect frost frequency.

However, studies of New Zealand temperatures indicate that natural variations cannot explain all of the changes seen over the past century, and that increasing global concentrations of greenhouse gases are also playing a part (Dean \& Stott 2009). This is consistent with the findings for the globe as a whole from the 2007 IPCC assessment (IPCC 2007), which stated: "Most of the observed increase in global average temperature since the mid-20th century is very likely due to the observed increase in anthropogenic greenhouse gas concentrations".

\section{Future projections - global and New Zealand}

We expect that climatic conditions in the future will, as in the past, respond to a combination of natural and anthropogenic causes. For example, a recent paper by Lean \& Rind (2009) discusses how a combination of El Niño events, possible volcanic eruptions, and solar changes could modify anthropogenic influences on globally-averaged temperatures over 2009 to 2014 and 2014 to 2019. However, over the longer term (looking decades into the future) anthropogenic warming is expected to be the dominant effect.

The size of the projected change later in the century depends on the quantity of greenhouse gases emitted from human activities in the meantime. This is illustrated here by considering global and regional projections for two possible scenarios, one is a "rapidly decarbonising world" resulting from global action to reduce greenhouse gas emissions and to stabilise greenhouse gas concentrations so that global temperature increase 
is limited in the long term to about $2^{\circ} \mathrm{C}$ above preindustrial levels. The second is a "high carbon world" with an increase in globally averaged temperature of about $3.8^{\circ} \mathrm{C}$ by the end of this century (compared to pre-industrial conditions).

Projections for these scenarios are summarised here from Mullan et al. (2009). The down-scaled projections for New Zealand suggest that for the "high carbon" world we could see a warming averaged over the country of about $2.6^{\circ} \mathrm{C}$ (relative to $1980-99$ ). The projection for the "rapidly decarbonising world" is for about $1.1^{\circ} \mathrm{C}$ warming by the end of the century.

For precipitation (rain + snow) in winter and spring, the projected pattern is for increases in the west of both islands, decreases in the east of both islands, and decreases in the north of the North Island. The amplitude of this pattern is projected to increase with time and with the magnitude of the global warming.

The projected spatial pattern of summer rainfall change is noticeably different from winter in the North Island: a decrease is projected for the southwest and an increase in the east. This pattern becomes more marked in the high carbon scenario by the end of the century, with up to $10 \%$ less summer rainfall in Taranaki, Wanganui and Manawatu and increases of $10 \%$ or larger in parts of Hawkes Bay and Gisborne by 2080-2099. These summer changes in the North Island are the opposite of those in winter, but smaller in magnitude, so the winter pattern is expected to dominate the annual average. The projections described in this paragraph come from averaging results from 12 different models. Mullan et al. (2009) also discuss the similarities and differences between the projections from individual models. These projections vary more between individual models for precipitation than for temperature.

Projections for other climate elements later in this century include:

For temperature extremes including frosts: Decreases in frost occurrence and increases in high maximum temperatures are expected.

For extreme rainfall: Increases in the frequency and magnitude of heavy rainfall are expected. Guidance from Mullan et al. (2008) suggests that a currently experienced extreme rainfall (e.g. 24-hour extreme with a 100 year return period) could occur approximately twice as often (i.e. 50-year return period) under a local warming of $2^{\circ} \mathrm{C}$. Increases in dry spells are also possible. Drought: Mullan et al. (2005) concluded from a study based on down-scaled projections from two climate models from the IPCC's Third (2001) assessment that current 1 -in-20 year drought could occur at least twice as often in eastern parts of New Zealand (parts of Northland, Bay of Plenty, Wairarapa, Marlborough, Canterbury and Otago) under a warming of about $2^{\circ} \mathrm{C}$.
Further research is currently underway to both update the study with the latest projections and examine the importance of plant responses to increasing carbon dioxide concentrations.

Extreme winds: Research is presently underway on how climate change might affect the strength of the strongest winds (those exceeded only $1 \%$ of the time) over New Zealand. Mullan et al. (2008) show initial model results suggesting an increase in these strongest winds over much of the country by 2100 . The projected changes are fairly small for the most part (averaging out at a $2.3 \%$ increase over all land points in the model), but reach about $10 \%$ in some eastern locations.

\section{Impacts and adaptation}

Only a limited amount of work has so far been published on the potential impacts of climate change on pastoral agricultural production in New Zealand, and more work is currently in progress. Tait et al. (2008) summarise results from a study based on some climate scenarios from the IPCC's Third (2001) assessment. For the climate scenarios considered, average year production (both dairy and sheep/beef) and worst-year production are both projected to decline in the periods 2020-2049 and 2070-2099 for some east coast locations and for Northland, compared to 1972 - 2002 conditions. However, improvements in production are projected in Southland and the West Coast regions which are projected to remain moist while warming.

As a result of coping with New Zealand's variable climate over the past few decades farmers in some parts of New Zealand have developed farm management practices which will also build resilience to some of the expected future changes. This includes prudent management of stock numbers through drought periods, use of more drought-tolerant pasture species in at-risk locations, and water management (including irrigation development). Other management changes could also be applied in future - with timing depending on whether the world goes down a "high carbon" or a "low carbon" future, and based on how quickly climate is observed to change here as a result. For example, if a region develops milder winters, earlier spring grass growth, and drier conditions later in the spring, farmers may choose to vary their stock management and pasture utilisation appropriately.

A key issue to consider is whether future climate changes will be outside the range of the coping strategies developed by New Zealand agriculture given past and current experience, and if they are, what adjustment can be made to expand that range. The value of considering projections is that they allow us to anticipate the likely size of changes, and initiate the right level of adjustment 
through research, planning and management. Another important issue is the expected relative impacts of climate changes on agricultural production in other countries which produce similar products to New Zealand. A further vital question for New Zealand, not considered in this paper, is that of potential global policy changes regarding mitigation of greenhouse gases and their impact on agricultural markets.

\section{REFERENCES}

Dean, S.M.; Stott, P.A. 2009. The effect of local circulation variability on the detection and attribution of New Zealand temperature trends. Journal of Climate (In press).

Griffiths, G.M. 2007. Changes in New Zealand daily rainfall extremes, 1930-2004. Weather and Climate 27: 3-44.

IPCC, 2007. Climate change 2007: Synthesis Report. Contribution of Working Groups I, II and III to the Fourth Assessment Report of the Intergovernmental Panel on Climate Change. Eds. Pachauri, R.K.; Reisinger, A. Geneva, Switzerland. 104 pp.

Lean, J.L.; Rind, D.H. 2009. How will Earth's surface temperature change in future decades? Geophysical Research Letters 36, L15708, DOI:10.1029/2009GL038932. 5 pp.

Mullan, A.B. 1995. On the linearity and stability of Southern Oscillation - climate relationships for New Zealand. International Journal of Climatology 15: 1365-1386.
Mullan, A.B.; Porteous, A.; Wratt, D.S.; Hollis, M. 2005. Changes in drought risk with climate change. NIWA Report to Ministry for the Environment and MAF, May 2005. (http://www.climatechange.govt. $\mathrm{nz} /$ resources/reports/drought-risk-may05/html/ index.html).

Mullan, A.B.; Wratt, D.S.; Dean, S.; Hollis, M.; Allan, S.; Williams, T.; Kenny, G. 2008. Climate Change Effects and Impacts Assessment: A Guidance Manual for Local Government in New Zealand. Second Edition. Ministry for the Environment, Wellington. 149 pp.

Mullan, A.B.; Reisinger, A.; Manning, M.; Wratt, D.; Nottage, R. 2009. Adaptation conference climate change scenario information. Background paper prepared for: Climate Change Adaptation - Managing the Unavoidable, Wellington, 21-22 May 2009. (Available from R Nottage, NZ Climate Change Centre, PO Box 14-901, Wellington).

Salinger, M.J.; Gray, W.; Mullan, A.B.; Wratt, D.S. 2004. Atmospheric Circulation and precipitation. In: Freshwaters of New Zealand. Eds. Harding, J.; Mosley, P.; Pearson, C.; Sorrell, B. New Zealand Hydrological Society. pp. 2.1-2.18.

Tait, A.; Baisden, T.; Wratt, D.; Mullan, A.B.; Stroombergen, A. 2008. An initial assessment of the potential effects of climate change on New Zealand agriculture. New Zealand Science Review 65: 50-56. 